believed to have surpassed those of any other comparable industrial country". Despite this achievement, however, the chief tasks in Mr Ireland's estimation are to reduce domestic emissions, internal combustion engine exhaust gases, grit and dust and, notwithstanding natural process, sulphur dioxide.

\section{NUCLEAR FUEL}

\section{Centriluge Pulls in Partners}

THere may soon be two new recruits to the European centrifuge club, if proposals submitted to the Italian and Belgian governments earlier this month are taken up. Although official comment is still scarce, it seems clear that the Italian Government in particular has been attracted by the offer of joining the centrifuge scheme with Britain, West Germany and the Netherlands for the production of enriched uranium, and may soon be negotiating its way into the project.

\section{Nuclear Sufeguards}

THE United Kingdom Atomic Energy Authority has now made public the steps which it has been taking in the past few years to devise instruments which can help with the automatic monitoring of the uses to which fissile material from nuclear reactors is put. The authority is one of several organizations engaged with the International Atomic Energy Agency in the development of techniques like this. Its particular interest is in the detection of the delayed neutrons which are given off after the fission of uranium or plutonium nuclei.

In one technique that has been developed at Aldermaston, $14 \mathrm{MeV}$ neutrons are used for irradiated samples, usually consisting of uranium swarf pressed into pellets or plutonium fragments packed under pressure into cylindrical plastic containers. After irradiation, the proportions of the two different materials can be determined by standard radioactive techniques for the detection of delayed neutrons, six groups of which may be emitted with half lives ranging from a fifth of a second to $\mathbf{5 5}$ seconds.

This method works best for highly enriched materials. For the analysis of fissile materials in solution, the authority has been working on gamma absorption, either directly through the walls of piping or tubing or by the construction of special cells at suitable places in a plant. It appears that the disadvantages of using absorption through constructional piping are considerable. A specially designed absorptiometer incorporating a plastic scintillator has been found satisfactory for gamma absorption measurements and obviously has a future in various separation plants. The authority's work does, however, suggest that electrolytic methods involving the measurement of the electrolytic potentials due to particular ions in solution may in the long run be one of the more convenient techniques.
The possibility of having an enrichment plant in Italy is naturally one of the chief benefits the Italian Government could hope to reap, and the prospect seems to be enticing. The exact role of a Belgian presence in the project seems more obscure, but one body that is likely to be jubilant over the likelihood of a wider European agreement is the European Commission itself. One of the ticklish points about the centrifuge agreement signed in February was that Britain was not a member of Euratom, and that under the Euratom treaty member states have to submit to the commission any draft agreements involving non-Euratom organizations. One objection the commission may have harboured was that Britain may be in a position to bar other members of Euratom from access to the enriched uranium. If Italy and Belgium now join, even the technicality of this objection will become wafer thin.

A reminder that the enriched fuel business is not the only one with commercial attractions came last week with the announcement that the UK Atomic Energy Authority had secured a contract from the American Combustion Engineering Company for the conversion of uranium concentrate to uranium hexafluoride. The deal is estimated to be worth between $£ 1$ million and $£ 1.5$ million. The conversion to hexafluoride is a vital step in the path from rough ore to enriched fuel suitable for reactor consumption and is the stage prior to the enrichment process, whether by gaseous diffusion or by centrifuge.

The order has come at a good time for the Production Group of the AEA. The present production of enriched uranium at Capenhurst is not sufficient to keep the hexafluoride plant at Springfield, Lancashire, at full stretch, and the completion of the centrifuge, with its capacity of 200 tons of uranium a year, is still a long way off. The production group, which trades as a separate entity and would have been amalgamated with the Radiochemical Centre at Amersham as a new fuel company under the programme of the previous government, will purchase uranium concentrates from US mining companies, convert to hexafluoride at Springfield, and deliver the high purity material for use in American gaseous diffusion plants.

\section{GERMANY \\ Poised for Aerospace Boom}

A substantial increase is expected to be announced shortly in the funds allocated by the Federal Government for projects in the German aircraft and aerospace industry. The Federal Ministry of Industry is seeking the approval of parliament for its plan to spend DM11,670 million ( $£ l, 348$ million) during the five years to the end of 1974 for projects in the air and space industry, about three-quarters of which will be for military aircraft and equipment.

The Federal Government's support for space projects shows a dramatic increase. The present estimate for the five-year period to 1974 is put at DM2,624 million compared with DM1,419 million for the period 1962-69. Although the figures are still provisional, the Federal authorities seem confident that the German air and space industry will soon emerge from the brief lull occasioned by a drop in new military projects and that production will soon be rising steeply again. The turnover of the industry, which 